was well displayed during a recent visit to the Continent I made with him for the purpose of inspecting the leading hospitals there. All the arrangements for the itinerary were made by him. This entailed an enormous amount of work-the writing of letters late into the night and often early in the morning during the whole of the tour -but so admirably was every detail worked out that not a single hitch occurred in the arrangements. Savill's absorption in work caused him at times to appear abrupt in manner, and to be neglectful of those little arts which make for popularity. Thus it was that he was not understood by everyone. Only in this way can I explain the fact that he was never elected to the Fellowship of the Royal College of Physicians, a distinction which he had long since richly merited. I myself never had any difficulty in understanding and appreciating the real man. Savill was an undemonstrative man, but one felt the good that was in him and the loyalty of his friendship, and this was all-sufficing. During our long friendship I never heard him speak unkindly of anyone. He has been suddenly snatched away just when he was beginning to reap the full reward of a brave and strenuous life, and those who knew him-really knew himmourn his tragic end.-I am, Sir, yours faithfully,

Wimpole-street, W., Jan. 25th, 1910.

HARRY CAMPBELL.

\section{THE PANCREATIC REACTION IN THE DIAGNOSIS OF DUODENAL ULCER.}

\section{To the Editor of THE LANCET.}

SIR,-I am much interested in a letter under the above heading in THE LANCET of Jan. 22nd, p. 269, and I can confirm the opinion expressed by Dr. G. Herschell as to the value of the pancreatic reaction in the diagnosis of duodenal ulcer in excluding functional hyperchlorhydria. It has probably escaped Dr. Herschell's notice that in my Hunterian lecture on Duodenal Ulcer and its Treatment, whinh was published in the British Medical Journal of Feb. 2nd, 1907, p. 248, will be found the following paragraph : "The presence of an excess of urobilin may indicate catarrh extending to the bile ducts, and the presence of pancreatic crystals, as shown by Cammidge's test, may point to catarrh extending up the pancreatic duct."

It should be borne in mind in estimating the value of this test that it is common both to duodenal ulcer and to cholelithiasis, both of which are associated with duodenal catarrh. In the former disease I have found it universally present, hence it has been my custom for some years in any case of doubtful diagnosis to avail myself of a pathological report, but in the latter condition the pancreatic reaction occurs only in about 70 per cent. of cases, so tbat in estimating the value of the test the presence of cholelithiasis has to be taken into consideration. My estimate of the value of this test has resulted from a considerable experience of duodenal ulcer, as, besides having operated on 150 cases, I have employed it in a large number of cases which were not operated on, but where the diagnosis was able to be subsequently verified.

I am, Sir, yours faithfully,

Park-crescent, W., Jan. 24th, $1910 . \quad$ A. W. MAYO RoBSON.

\section{THE EYE-SIGHT OF MOTOR DRIVERS.}

\section{To the Eatitor of THE LANCET.}

SIR, - The drivers of motor cabs, omnibuses, and other public vehicles are required to pass certain tests for vision, and thus one source of danger to the public is guarded against. It is doubtful if more than a very small proportion of the owners of private motor-cars ever make inquiries concerning the sight of their chauffeurs. The three following examples of gross defect of sight in drivers of private cars have recently come under my notice.

1. An owner who usually drives his car; myopia of high legree, wears glasses when driving, with which his vision is : R. eye. $6 / 36$, imperfectly; L. eye, $6 / 60$. He states that he has " no difficulty except when the light is dull."

2. Chauffeur, in the employ of a private owner. High degree of hypermetropic astigmatism. Left eye congenitally amblyopic; right sees $6 / 18$ badly, and can be improved to $6 / 9$, but with a full w correcting lens patient is uncomfortable and consequently does not usually wear glasses when driving.
Occasionally, "if the light is bad," he wears glasses which partially correct the refractive error and give vision of 6/12.

3. Chauffeur, in the employ of a motor manufacturer and proprietor. He is not a regular driver but is often sent out with cars. He is blind in the left eye; sight lost after operation in childhood. In the right there is a congenital cataract and the sight is only $4 / 60$, not improved by lenses. He stated voluntarily that he could not tell whether a vehicle was approaching or going from him until he was " right on it." I am, Sir, yours faithfully, Harley-street, W., Jan. 24th, 1910. J. B. LAWFORD.

\section{THE STATE REGISTRATION OF NURSES. To the Editor of THE LANCET.}

SIR,-In the heat and worry of electioneering I must be forgiven if I do not reply at length to Dr. J. M. Mason's letter, in which he comments on an excellent speech I made at the meeting of the Cottage Benefit Nursing Society. I thank him, at any rate, for replying to it in a very different spirit to that which is generally vouchsafed to me by the advocates of the registration of nurses.

Dr. Mason writes that " no one suggests, as Mr. Holland assumes, that because a nurse has passed a State examination therefore she has all the attributes of the best nurse." But unfortunately this is suggested, and certainly the public would be led to believe that in engaging a registered nurse they would be securing a competent and suitable nurse. Let us see what Lady Helen Ferguson, one of their ablest advocates, has written: "The continuance of a nurse's name on the register would be a guarantee [Mark this. S. H.] of her professional fitness--general fitness for employment"!

As a fact, it would guarantee nothing except that, perhaps many years before, she had passed what must necessarily be an easy examination, and had left her training school with a good character. And no guaranteeing body would really know anything of her afterwards. Registration would secure to the public neither professional fitness nor fitness of character. It is not the remedy for the present chaos, and a false remedy is worse than a known danger.

I learn that the nurses are not registering in the State of New York where they have a Registration Act, and I will prophesy that if passed in England, which is not likely, after the novelty of the thing has worn off, nurses in England, certainly the best, will not register. It may help the bad, of course. If anyone is interested enough to care to read my speech I shall be happy to send him a copy.

I am, Sir, yours faithfully,

Royston, Herts, Jan. 21st, 1910. SYDNEY Holland.

\section{"A VICTIM TO SCIENCE."}

\section{To the Editur of THE LANCET.}

SIR,-As a neighbour of $\mathrm{Mr}$. Cox, the " $\mathrm{X}$ ray martyr, and conversant with the facts of the case, I thank you for your annotation of Saturday last and for the insertion of Mr. F. W. Alexander's letter in support of Sir William Treloar's appeal. Mr. Alexander's statement is no exaggeration when he says "that a more pitiable case I have never witnessed in any human being during my 32 years' professional career." Words fail to express the pathetic condition of the man who has sacrificed health and fortune for the benefit of his race, and who bears his sufferings with heroic fortitude. Testimonies are daily to hand from leading members of the medical profession expressing their indebtedness to Mr. Cox, whose work they acknowledge to have been of the greatest service. Visiting him the other day he said, "When I was working with the doctors I little thought the help I was rendering would return to me in such geverous sympathy as I am receiving from them now." Mr. Cox's medical attendant, Dr. R. Taylor, says : "It is not outside my professional office to mention the very great deal which this public action is meaning to him, both as a comfort to his fatal trouble and as a hope of leaving his family in some measure provided for." Mr. Cox is in his forty-seventh year, and when able to follow his calling was an enthusiast in scientific research. Generous and self-sacrificing, he lived for others, and was always ready to give the $X$ ray treatment freely to the poor who could not afford to pay. Sir William Treloar in raising a fund for Mr. 